\title{
Nutritional impact on intestinal bacterial communities of pigs studied by molecular biology techniques
}

\author{
O. Simon ${ }^{1}$, D. Taras and W. Vahjen \\ Institute of Animal Nutrition, Free University of Berlin \\ Bruemmerstr 34, 14195 Germany
}

\begin{abstract}
In this contribution compositional shifts of intestinal bacterial communities in response to different nutritional factors (enzymes, probiotics, rare earth elements) are reported, as determined with nucleic acid based methods, i.e. 16S RNA probes, denaturing gradient gel electrophoresis, Real-time PCR, Multiplex PCR. These techniques enabled the detection of a promotion of jejunal L. reuteri activity by xylanase as well as a reduction of the E. faecalis/E. faecium ratio and frequency of potentially pathogenic $E$. coli in piglets by probiotic supplementation. While the probotic altered the faecal microbiota of sows, an influence of REE on species composition in faeces of weaned piglets was not detectable by DGGE.
\end{abstract}

KEY WORDS: intestinal bacteria, molecular biology methods, xylanase, probiotics, Enterococcus faecium NCIMB 10415, pigs

\section{INTRODUCTION}

During the development into adulthood a multitude of changes occur within the intestinal tract of animals. These are most pronounced upon birth, first uptake of solid feed and at the time of weaning and are often linked to "intestinal disorders", i.e. nutrient malabsorption, or diarrhoea leading to reduced overall animal performance. Most of these intestinal disorders are of microbial origin. However, understanding of modifications within the intestinal microbial community requires the application of more sensitive techniques than provided by means of conventional microbiology. This contribution exemplifies some advantages of nucleic acid based methods in taxonomic resolution when studying the species specific responses of intestinal bacteria to different nutritional factors.

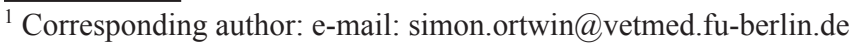




\section{MATERIAL AND METHODS}

Results of three experiments with pigs, Landrace $\times$ Duroc, are reported. In the first trial, a wheat/rye based diet contained $0.04 \%$ xylanase $(1192 \mathrm{IU} / \mathrm{g})$ was administrated for three weeks to weaned piglets before sacrifice. 16S rRNA targeted oligonucleotide probes specific for various Lactobacillus species were used to analyse RNA extracts of jejunum digesta using the dot blot technique (Loh, 2002).

The second trial comprised the monitoring of the faecal microbiota of gestating sows, either receiving a control diet based on wheat and barley or the control diet supplemented with a probiotic strain, Enterococcus faecium NCIMB 10415. DNA from faecal samples was extracted, the V6-V8 region of the 16S rRNA gene was amplified and denaturing gradient gel electrophoresis (DGGE) performed essentially as descried by Zoetendal et al. (2001). Piglets of these sows receiving the respective supplementation were sacrificed and specific cell numbers of E. faecium and E. faecalis in intestinal contents were determined with Real-time PCR assays. Primer pairs directed against five adhesion and four toxin gene sequences of Escherichia coli according to Göbel (2003) were used in order to identify the frequency of these genes in E. coli isolates from probiotic and control animals using multiplex PCR.

Weaned piglets, which fed either on a rare earth element diet (REE, $200 \mathrm{mg}$ / $\mathrm{kg}$ ) or a control diet, composed the third trial. After a six week administration of REE faecal samples of both treatment groups were compared using DGGE of PCR amplicons as described above.

\section{RESULTS AND DISCUSSION}

Enzymes - study of the Lactobacillus population using 16S RNA probes. We compared the rRNA content as measure for metabolic activity of selected Lactobacillus species in jejunum segments relative to the total Lactobacillus spp. metabolic activity (Figure 1A). The most striking observation was the result that the six employed species probes covered less than half of the total Lactobacillus spp. activity in proximal jejunum samples of control animals, in the enzyme treated group even less than $20 \%$. The employed species probe set covered a gradually declining fraction of all Lactobacillus spp. in central and terminal jejunum segments of control piglets, but the enzyme treated group was dominated by $L$. reuteri. This implies that the control group harboured an increasing proportion of other - presumable unknown - Lactobacillus species, while L. reuteri was able to benefit from enzyme inclusion. Another interesting finding was the reduced activity of L. mucosae, a mucus associated Lactobacillus species in the enzyme treated group. The lower detection of a mucus associated bacterium in the lumen of the enzyme group may indicate a reduced shedding of epithelial cells. 

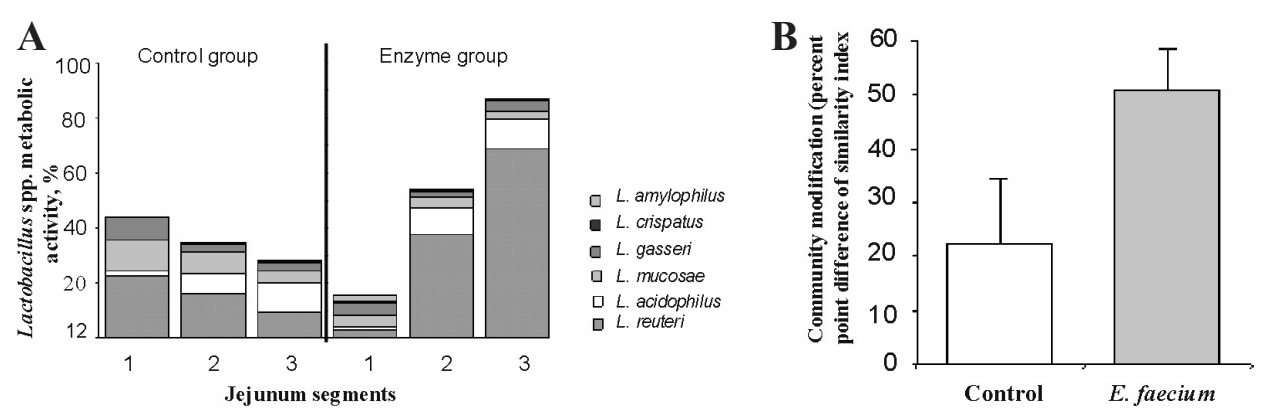

Figure 1. A. Effect of xylanase supplementation on the metabolic activity of lactobacillus species in three equal parts of the small intestine of piglets. B. Modification (percent point difference) of faecal microbiota of gestating sows determined by comparison of DGGE banding patterns of two successive samples (first sample before supplementation started vs. second sample after two month continuous administration of control and probiotic feed, respectively)

Probiotics - characterization of intestinal microbiota by DGGE, Real-time $P C R$ and Multiplex PCR. Using denaturing gradient gel electrophoresis (DGGE) of $16 \mathrm{~S}$ rDNA PCR amplicons we compared the dominant faecal bacterial communities of sows before and after continuous probiotic supplementation $(E$. faecium). During a period of two month the probiotic strain led to a significant greater modification of the faecal microbiota of gestating sows than in the control group as judged by Sørensen's pair-wise similarity index (Figure 1B), which failed to appear using microbiological methods based on culture ability (Scharek et al., 2005). This observation may be of crucial importance for the development of newborn piglets, whose intestinal community is dominated by bacterial strains (beneficial or detrimental) of maternal origin.

Furthermore, this study investigated the ability of the same probiotic strain to modify indigenous E. faecium and E. faecalis cell numbers in the intestinal tract of piglets. The results confirm earlier findings on the low ratio of specific colony counts of the probiotic strain to total enterococci in probiotic fed piglets and shows that the probiotic is also not a major member of the intestinal E. faecium population. On the other hand, the probiotic was able to suppress E. faecalis and may rearrange enterococcal populations with consequences for other bacterial populations.

Application of multiplex PCR in the same animals revealed a high diversity with varying frequency and distribution of each pathogenicity gene. In general, young piglets ( 7 and 14 days of age) of probiotic treated mother sows exhibited isolates without any pathogenicity gene in higher frequency (54 vs 37\%) and even comprised animals carrying exclusively isolates without any pathogenicity genes compared to control piglets ( 25 vs $0 \%$ ).

Rare earth elements - diversity of the faecal bacterial population by DGGE. DGGE may provide a useful tool for preliminary bacterial community analysis 
respective their often suggested alteration after rare earth element supplementation. The dominant microbiota of faecal samples showed no significant quantitative (richness $25 \pm 4$ vs $25 \pm 6$ ) or qualitative (shannon's diversity index $2.8 \pm 0.2$ vs $2.8 \pm 0.2$ ) difference between control and supplementation group. In addition, DGGE banding pattern revealed comparable similarity (\%) of bacterial commu-

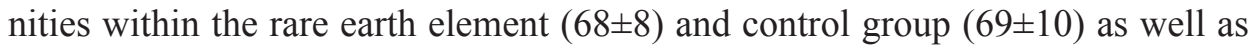
between groups (66 \pm 8$)$. These results do not support the hypothesis of an effect of REE via modifications of the intestinal microbiota.

\section{CONCLUSIONS}

The use of nucleic acid based methods allows the detailed analysis of bacterial interactions in the intestine and is superior to classic microbiology. Molecular biology methods however should be supplemented with other bacteriological parameters in order to broaden the picture on bacterial metabolic activities as well as characterize the full functional potential and interaction of yet unknown bacterial strains.

\section{REFERENCES}

Göbel S., 2003. Multiplex-Polymerase-Ketten-Reaktion (mPCR) zum Nachweis ausgewählter Virulenzfaktoren schweinepathogener Escherichia coli - Einsatz bei Ferkeln mit Bacillus cereus var. toyoi Zulage. Vet. med. Thesis. Freie Universität Berlin (Germany)

Loh, G., 2002. Application of rRNA oligonucleotide probes for the detection of nutritional influences on bacterial metabolic activities in the gastrointestinal tract of broilers. Vet. med. Thesis. Freie Universität Berlin (Germany)

Scharek L., Guth J., Reiter K., Weyrauch K.D., Taras D., Schwerk P., Schmidt M.F.G., Wieler L.H., Tedin K., 2005. Influence of a probiotic E. faecium strain on development of the immune system of sows and piglets. Vet. Immunol. Immunopathol. (in press)

Zoetendal E.G., Ben-Amor K., Akkermans A.D., Akkermans-van Vliet W.M., de Visser J.A.G.M., De Vos W.M., 2001. The host genotype affects the bacterial community in the human gastrointestinal tract. Microbial Ecol. Health Dis. 13, 129-134

\section{STRESZCZENIE}

\section{Czynniki żywieniowe a kolonie bakterii jelitowych u świń}

Stwierdzono zmiany składu kolonii bakterii jelitowych w odpowiedzi na różne czynniki żywieniowe (enzymy, probiotyki, pierwiastki ziem rzadkich (REE), przy zastosowaniu metody opartej na oznaczaniu kwasów nukleinowych, tj. 16S RNA, elektoforezy na żelu w denaturowanym gradiencie (DGGE), real time PCR, Multiplex PCR. Te techniki pozwoliły na wykrycie stymulacji aktywności L. reuteri w jelicie czczym przez ksylanazę, jak również zmniejszenie stosunku E. faecalis/E. faecium oraz częstotliwości występowania potencjalnie patogennego E. coli u prosiąt otrzymujących dodatek probiotyku. Podczas gdy probiotyki zmieniały florę bakteryjną kału macior, to nie wykryto wpływu REE na skład gatunkowy bakterii w kale odsadzonych prosiąt, stosując DGGE. 